\title{
Comparison of thyroid function in different emotional states of drug-naïve patients with bipolar disorder
}

\author{
Shengnan Zhao ${ }^{1}$, Xu Zhang ${ }^{2}$, Yaling Zhou1', Hao Xu1, Yuwei Li', Yuexin Chen², Bo Zhang ${ }^{1 *}$ and Xueli Sun ${ }^{1 *}$
}

\begin{abstract}
Background: Previous studies have shown that bipolar disorder is closely related to thyroid dysfunction. Psychiatric drugs have a large or small effect on thyroid function, and thyroid hormone levels can also affect the effect of drug treatment. Therefore, the purpose of this study is assessment the thyroid function of drug-naive bipolar disorder across different mood states, with the expectation of providing support for treatment options.

Methods: The present study is a cross-sectional study. Patients diagnosed with bipolar disorder according to the International Classification of Diseases diagnostic Criteria, Edition 10 (ICD 10) and who had never received medication were included in the study. The Montgomery Depression Scale (MADRS) was used to assess depressive symptoms and the Young Mania Rating Scale (YMRS) for manic symptoms. Thyroid function indicators include thyroid-stimulating hormone (TSH), free triiodothyronine (FT3), total triiodothyronine (TT3), free thyroxine (FT4), and total thyroxine (TT4). Levels of TSH, $T 44, F T 4, T 3$, and FT3 were measured within $48 \mathrm{~h}$ of hospitalization, between 06:00 and 08:00.
\end{abstract}

Results: The data analysis finally covered the data of 291 subjects (136 in a bipolar manic group, 128 in a bipolar depressive group, and 27 in a bipolar mixed group), including 140 males and 151 females, with an average age of $27.38 \pm 8.01$. There was no significant difference in age, sex, marital status, work status, family history, and course of illness among the manic group, depressive group, and mixed group. The level of FT3, the rate of thyroid hormone increased secretion, and the total abnormality rate of thyroid hormone secretion in the manic group were significantly higher than those in the depressive group.

Conclusion: These findings indicate that thyroid functions were significantly different between depressive and manic episodes in BD patients. In clinical practice, it is necessary to take into account the differences in thyroid hormone levels in patients with BD across different emotional states in choosing drug.

Keywords: Bipolar disorder, Bipolar depression, Bipolar mania, Thyroid function

\footnotetext{
*Correspondence: zb_73@126.com; sunxuelihx@163.com

${ }^{1}$ Mental Health Center, West China Hospital, Sichuan University, Chengdu, Sichuan, China

Full list of author information is available at the end of the article
}

(c) The Author(s). 2021 Open Access This article is licensed under a Creative Commons Attribution 4.0 International License, which permits use, sharing, adaptation, distribution and reproduction in any medium or format, as long as you give appropriate credit to the original author(s) and the source, provide a link to the Creative Commons licence, and indicate if changes were made. The images or other third party material in this article are included in the article's Creative Commons licence, unless indicated otherwise in a credit line to the material. If material is not included in the article's Creative Commons licence and your intended use is not permitted by statutory regulation or exceeds the permitted use, you will need to obtain permission directly from the copyright holder. To view a copy of this licence, visit http://creativecommons.org/licenses/by/4.0/ The Creative Commons Public Domain Dedication waiver (http://creativecommons.org/publicdomain/zero/1.0/) applies to the data made available in this article, unless otherwise stated in a credit line to the data. 


\section{Background}

Bipolar disorder (BD) is a chronic episodic illness. It affects more than $1 \%$ of the global population [1], with a lifetime prevalence of $0.4-2.4 \%$ according to different diagnostic criteria [2]. It has been eating into the vitals of humankind, leading to obesity, loss of work efficiency, impairment of mental functions, deteriorating social relationships, and finally, deliberate self-harm [1, 3-8]. In the World Health Organization (WHO) World Mental Health (WMH) surveys, BD was the second greatest influential of the nine mental disorders and 10 chronic physical disorders surveyed that affected days out of the role [9]. Also, suicide is quite frequent among the population with $\mathrm{BD}$, with the risk of suicide death is up to 10-30 times higher than that of the general population [10].

One of the traits of BD is fluctuations in mood state. The clinical manifestations in patients with BD are extremely diverse, ranging from mild hypomania or mild depression to severe forms of mania or depression accompanied by profound psychotic symptoms. This alternation can occur spontaneously or be triggered by pharmacologic and psychological factors. First, many studies suggest that many types of medications are able to interfere thyroid function, affecting different parts of the functional thyroid circuit, such as lithium [11], quetiapine and olanzapine [12]. Besides, previous studies have shown that different neurotransmitters and neuroactive steroids monoamines, for example melatonin, cortisol, thyroid hormones et.al, may be involved in the pathogenesis of $\mathrm{BD}$, and the hypothalamic-pituitary-thyroid (HPT) axis is the prime candidate $[1,13]$. It has been proposed low thyroid function is associated with the depressive phase of $\mathrm{BD}$, due to the antidepressant effect of thyroid hormone in the treatment of bipolar depression [14]. An early report showed that, among patients admitted to hospital due to bipolar depression, those with low baseline TSH levels were more likely to switch to mania [15]. Besides, milder fluctuations in mood in BD patients seem to correlate with the TSH response to $\mathrm{TRH}$ stimulation: Increasing severity of mood symptoms seems to be associated with reduced TSH response [16]. Accordingly, changes in thyroid function may cause fluctuations in patients with BD. In other words, thyroid function in $\mathrm{BD}$ patients across different emotional states may be different. Further, the thyroid hormone levels can affect the patient's response to drug therapy. Thyroid dysfunction is associated with poor treatment response in bipolar depression [17]. Therefore, a comprehensive understanding of thyroid function in drug-naive BD patients is essential. The purpose of the present study was to investigate and describe the thyroid function in drug-naive $\mathrm{BD}$ patients across different, with the expectation of providing support for treatment options.

\section{Methods}

The current study was a cross-sectional study on thyroid profile, and it was conducted at the Mental Health Center of West China Hospital from December 2018 to December 2019. Thyroid function indicators include thyroid-stimulating hormone (TSH), free triiodothyronine (FT3), total triiodothyronine (TT3), free thyroxine (FT4), and total thyroxine (TT4). All subjects were inpatients and diagnosed independently by two senior doctors, and only patients with the same diagnosis were included in the study. Inclusion criteria:1) ages 18 to 65 years old; 2) a discharge diagnosis with $\mathrm{BD}$ according to the International Classification of Diseases diagnostic Criteria, Edition 10(ICD 10)(F31.0-F31.7); 3) drug-naïve before hospitalization. Exclusion criteria included: 1) having comorbid diagnoses of other psychiatric disorders, such as schizophrenia; 2) having serious physical illnesses that needed medications; 3) having evidence of any known autoimmune diseases; 4) pregnant or lactating women; 5) having a history of thyroid disease. All subjects signed informed consent. The China Ethics Committee approved this research of Registering Clinical Trails (ChiECRCT-80,187). And this study completed the clinical trial registration: Chinese Clinical Trials Registry, ChiCTR1800019064, registered 24 October 2018, http://www.chictr.org.cn.

For all subjects, the Montgomery Depression Scale (MADRS) was used to assess depressive symptoms and the Young Mania Rating Scale (YMRS) for manic symptoms. Levels of TSH, TT4, FT4, TT3, and FT3 were measured within $48 \mathrm{~h}$ of hospitalization, between 06: 00 and 08:00, and blood samples were examined by the laboratory department of west China hospital. Specifically, TSH was detected by electrochemical luminescence double antibody sandwich method, and TT3, FT3, TT4, and FT4 were determined by electrochemical luminescence quantitative analysis (TSH Elecsys cobas e 200, T3 Elecsys cobas e 200, FT3 Elecsys G3 cobas e 200, T4 Elecsys cobas e 200 V2, FT4 Elecsys G2 cobas e 200, all Roche Diagnostics GmbH product). And the stock levels for TSH, FT3, TT3, FT4, and TT4 for healthy subjects, provided by the laboratory department, were $0.27-4.20$ $\mathrm{mU} / \mathrm{L}, \quad 3.60-7.50 \mathrm{pmol} / \mathrm{L}, \quad 1.30-3.10 \mathrm{nmol} / \mathrm{L}, \quad 12.00-$ $22.00 \mathrm{pmol} / \mathrm{L}, 62.00-164.00 \mathrm{nmol} / \mathrm{L}$. Increased thyroid hormone secretion (ITHS): at least one of the following indicators is abnormal, decreased TSH $(<0.27 \mathrm{mIU} / \mathrm{L})$, increased TT3 $(>7.50 \mathrm{pmol} / \mathrm{L})$, increased FT3 $(>3.10$ $\mathrm{nmol} / \mathrm{L})$, increased TT4 (>22.00 pmol/L), increased FT4 (>164.00 nmol/L). Decreased thyroid hormone secretion (DTHS): increased TSH $(>4.20 \mathrm{mU} / \mathrm{L})$, decreased TT3 $(<3.60 \mathrm{pmol} / \mathrm{L}), \quad$ decreased $\mathrm{FT} 3 \quad(<1.30 \mathrm{nmol} / \mathrm{L})$, 
decreased TT4 $(<12.00 \mathrm{pmol} / \mathrm{L})$, decreased FT4 $(<62.00$ $\mathrm{nmol} / \mathrm{L}$ ), at least one of the above item abnormal.

All data were analyzed by the statistical package IBM SPSS Statistics software (SPSS). ANOVA or $\mathrm{X}^{2}$ tests were performed to test for differences in sociodemographic variables. ANOVA tests was used to compare the hormone levels in different diagnostic subgroups, and $\mathrm{X}^{2}$ test for the incidences of abnormal hormone secretion in different diagnostic subgroups. Pearson's correlation analysis was used to evaluate the correlations among all hormone indicators, demography, total scores of MADRS, total scores of YMRS. All analyses used the two-tailed estimation of significance. All statistically significant $p$ values were set at $<0.05$.

\section{Results}

Demographic and clinical characteristics data

After applying exclusion criteria, 297 patients with BD were included. In total, 136 people were in the bipolar mania group (BD-M), of whom 16 were hypomanic episodes (BD-M I), 60 were manic episodes without psychotic symptoms (BD-M II), and 60 were manic episodes with psychotic symptoms (BD-M III). There were 128 people in the bipolar depression group (BD-D), among whom 62 were mild to the moderate depressive episode (BD-D I), 43 were major depressive episode without psychotic symptoms (BD-D II), and 23 were major depressive episode with psychotic symptoms (BD-D III). There were 27 patients in the mixed group (BD-MIX) and 6 patients in the remission group (BD-R). The remission group was not included in the data analysis due to its small number.

For the whole study, 291 patients were included in the final data analysis, $140(48.11 \%)$ were male, and 151 (51.89\%) were female. 149(51.20\%) had a junior high school degree or below, 73(25.09\%)had a high school or junior college degree, and 69 (23.71\%)had bachelor degree or above. 132(45.36\%)were unmarried, $126(43.30 \%)$ were married, and 33(11.34\%)were divorced or widowed. The mean age was $27.38 \pm 8.01$ years, the mean age of onset was $20.72 \pm 6.26$ years, and the illness duration was $6.66 \pm 4.98$ years. And the mean value of TSH, TT4, FT4, TT3, and FT3 were $2.29 \pm 1.47 \mathrm{mU} / \mathrm{L}, \quad 1.66 \pm 1.32 \mathrm{nmol} / \mathrm{L}, \quad 6.03 \pm 10.23$ $\mathrm{pmol} / \mathrm{L}, 71.88 \pm 39.45 \mathrm{nmol} / \mathrm{L}$, and $13.60 \pm 7.23 \mathrm{pmol} / \mathrm{L}$, respectively. The specific demographic and clinical characteristics information of different diagnostic subgroups is shown in Table 1. As show in Table 1, there were no significant difference in age, sex, educational background, marital status, family history and entire disease course among different diagnostic subgroups.
The serum thyroid hormone levels among different diagnostic subgroups

As can be seen from Table 1, TSH, TT3, TT4 and FT4 levels showed no significant differences between the three diagnostic subgroups or the further seven diagnostic subgroups. However, it was found that the FT3 level was significantly different among the 7 diagnostic subgroups. Specifically, FT3: BD-M II > BD-MIX, BD-D I, BD-D II and BD-D III $(p=0.037, p=0.004, p=0.006$, $p=0.045$ ), and there was no significant difference between the remaining groups. Comparing three combined groups, BD-M, BD-MIX, and BD-D, a difference still lay in FT3 levels. BD-M $>$ BD-D $(p=0.003)$, and there was no significant difference between BD-M and BD-MIX $(p=0.116)$ and between BD-D and BD-MIX $(p=0.842)$.

\section{The incidences of abnormal hormone secretion among different diagnostic subgroups}

The abnormality rates of thyroid hormone secretion in different diagnostic subgroups are shown in Table 2 . First, comparison was performed on the increase probability of thyroid hormone secretion. Upon comparison, the 7 diagnostic subgroups were different overall (Fisher $=17.595, p=0.002$ ), but after Bonferroni correction, only the increase rate of thyroid hormone secretion of BD-M II was significantly higher than that of BD-D II $(20.00 \%$ vs $1.61 \%$, pp. $<0.005)$. Comparing the three combined groups, BD-M, BD-MIX, and BD-D, a difference still lay in the overall distribution of the increase rate of thyroid hormone secretion $(20.59,7.41,1.56 \%$; $\mathrm{X}^{2}=28.469, p=0.000$ ), but after Bonferroni correction, only the increase rate of thyroid hormone secretion of BD-M was significantly higher than that of BD-D $(20.59 \%$ vs $1.56 \%$, pp. $<0.005)$. Second, the comparison was performed on the decrease probability of thyroid hormone secretion. No significant difference was found from the comparison among the 7 diagnostic subgroups or among the 3 diagnostic subgroups combined $\left(\mathrm{X}^{2}=\right.$ 6.172, $\left.p=0.409 ; \mathrm{X}^{2}=0.656, p=0.718\right)$. At last, comparison is performed on the total abnormality rate (increase + decrease). Upon comparison, the 7 diagnostic subgroups were different overall $\left(\mathrm{X}^{2}=12.822, p=0.045\right)$, but after Bonferroni correction, only the abnormality rate of thyroid hormone secretion of BD-M II was found to be significantly higher than that of BD-D III $(70.00 \%$ vs $30.43 \%$, pp. $<0.005)$. Comparing the three combined groups, BD-M, BD-MIX, and BD-D, a difference still lay in the overall distribution of the increase rate of thyroid hormone secretion $\left(69.85,51.85,45.31 \%, X^{2}=15.676\right.$, $p=0.000$ ), but after Bonferroni correction, only the abnormality rate of thyroid hormone secretion of BD-M was found to be significantly higher than that of BD-D (69.85\% vs $45.31 \%$, pp. $<0.005)$. 
Table 1 Demographic and clinical data (mean \pm SD) / ( $\mathrm{n}, \%)$

\begin{tabular}{|c|c|c|c|c|c|c|c|c|c|c|c|c|}
\hline & \multicolumn{4}{|c|}{ The bipolar manic group(BD-M) } & \multirow{2}{*}{$\begin{array}{l}\text { The } \\
\text { mixed } \\
\text { group } \\
\text { (BD-MIX) }\end{array}$} & \multicolumn{4}{|c|}{ The bipolar depressive group(BD-D) } & \multirow[t]{2}{*}{ total } & \multirow[t]{2}{*}{$F / X^{2}$} & \multirow[t]{2}{*}{$p$} \\
\hline & BD-M I & BD-M II & BD-M III & total & & BD-D I & BD-D II & BD-D III & total & & & \\
\hline Number & 16 & 60 & 60 & 136 & 27 & 62 & 43 & 23 & 128 & 291 & - & - \\
\hline Age (years) & $\begin{array}{l}27.19 \pm \\
10.94\end{array}$ & $\begin{array}{l}29.71 \pm \\
7.70\end{array}$ & $\begin{array}{l}26.62 \pm \\
7.77\end{array}$ & $\begin{array}{l}27.81 \pm \\
8.62\end{array}$ & $\begin{array}{l}27.41 \pm \\
8.96\end{array}$ & $\begin{array}{l}25.95 \pm \\
5.71\end{array}$ & $\begin{array}{l}28.91 \pm \\
8.13\end{array}$ & $\begin{array}{l}25.78 \pm \\
7.29\end{array}$ & $\begin{array}{l}26.91 \pm \\
7.04\end{array}$ & $\begin{array}{l}27.38 \pm \\
8.01\end{array}$ & $\begin{array}{l}1.366^{\mathrm{a}} \\
0.409^{\mathrm{b}}\end{array}$ & $\begin{array}{l}0.241^{\mathrm{a}} \\
0.665^{\mathrm{b}}\end{array}$ \\
\hline \multicolumn{13}{|l|}{ Sex } \\
\hline male & $4(25.00)$ & $25(41.67)$ & $28(46.67)$ & $71(52.21)$ & $11(40.74)$ & $28(45.16)$ & $12(27.91)$ & $13(56.52)$ & $53(41.41)$ & $\begin{array}{l}140 \\
(48.11)\end{array}$ & $8.208^{\mathrm{a}}$ & $0.223^{\mathrm{a}}$ \\
\hline female & $12(75.00)$ & $35(58.33)$ & $32(53.33)$ & $65(47.79)$ & $16(59.26)$ & $34(54.84)$ & $31(72.09)$ & $10(43.48)$ & 75 (58.59) & $\begin{array}{l}151 \\
(51.89)\end{array}$ & $4.563^{b}$ & $0.102^{b}$ \\
\hline \multicolumn{13}{|l|}{ Educational } \\
\hline junior High school and below & $8(50.00)$ & $40(66.67)$ & $20(33.33)$ & $68(50.00)$ & $15(55.56)$ & $32(51.61)$ & $23(34.88)$ & $11(53.49)$ & $66(51.56)$ & $\begin{array}{l}149 \\
(51.20)\end{array}$ & $\begin{array}{l}18.442^{\mathrm{a}} \\
0.413^{\mathrm{b}}\end{array}$ & $\begin{array}{l}0.103^{\mathrm{a}} \\
0.981^{\mathrm{b}}\end{array}$ \\
\hline $\begin{array}{l}\text { high school and technical } \\
\text { secondary school }\end{array}$ & $5(31.25)$ & $7(11.67)$ & $24(40.00)$ & $36(26.47)$ & $6(22.22)$ & $15(24.19)$ & $9(39.53)$ & $7(20.93)$ & $31(24.22)$ & 73 (25.09) & & \\
\hline bachelor degree or above & $3(18.75)$ & $13(21.67)$ & $16(26.67)$ & $32(23.53)$ & $6(22.22)$ & 15 (24.19) & $11(25.58)$ & $5(25.58)$ & $31(24.22)$ & $69(23.71)$ & & \\
\hline \multicolumn{13}{|l|}{ Marital status } \\
\hline unmarried & $9(56.25)$ & $25(41.67)$ & $32(53.33)$ & $66(48.53)$ & $17(62.96)$ & $22(35.48)$ & $15(34.88)$ & $12(52.17)$ & $49(38.28)$ & $\begin{array}{l}132 \\
(45.36)\end{array}$ & $\begin{array}{l}19.284^{\mathrm{a}} \\
6.932^{\mathrm{b}}\end{array}$ & $\begin{array}{l}0.082^{\mathrm{a}} \\
0.140^{\mathrm{b}}\end{array}$ \\
\hline married & $6(37.50)$ & $27(45.00)$ & $24(40.00)$ & $57(41.91)$ & $8(29.63)$ & $34(54.84)$ & $22(51.16)$ & $5(21.74)$ & $61(47.66)$ & $\begin{array}{l}126 \\
(43.30)\end{array}$ & & \\
\hline divorced or widowed & $1(6.25)$ & $8(13.33)$ & $4(6.67)$ & $13(9.56)$ & $2(7.41)$ & $6(9.68)$ & $6(13.95)$ & $6(26.09)$ & $18(14.06)$ & $33(11.34)$ & & \\
\hline \multicolumn{13}{|l|}{ Employment } \\
\hline on-the-job or student & $14(87.50)$ & $40(66.67)$ & $32(53.33)$ & $86(63.24)$ & $14(51.85)$ & $41(66.13)$ & $32(74.42)$ & $16(69.57)$ & $69(53.91)$ & $\begin{array}{l}169 \\
(58.08)\end{array}$ & $\begin{array}{l}11.189^{a} \\
3.390^{b}\end{array}$ & $\begin{array}{l}0.083^{\mathrm{a}} \\
0.184^{\mathrm{b}}\end{array}$ \\
\hline $\begin{array}{l}\text { unemployment (including } \\
\text { retirement) }\end{array}$ & $2(12.50)$ & 20 (33.33) & $28(46.67)$ & $50(36.76)$ & $13(48.15)$ & $21(33.87)$ & $11(25.58)$ & $7(30.43)$ & $59(46.09)$ & $\begin{array}{l}122 \\
(41.92)\end{array}$ & & \\
\hline \multicolumn{13}{|l|}{ Family history } \\
\hline no & $12(75.00)$ & $47(78.33)$ & $51(85.00)$ & $\begin{array}{l}110 \\
(80.88)\end{array}$ & $20(59.26)$ & $48(77.42)$ & $35(81.40)$ & $19(82.61)$ & $\begin{array}{l}102 \\
(79.69)\end{array}$ & $\begin{array}{l}232 \\
(79.73)\end{array}$ & $9.925^{\mathrm{a}}$ & $0.128^{\mathrm{a}}$ \\
\hline yes & $4(25.00)$ & $13(21.67)$ & $9(15.00)$ & $26(19.12)$ & $7(40.74)$ & $14(22.58)$ & $8(18.60)$ & $4(17.39)$ & $26(20.31)$ & $59(22.61)$ & $0.192^{b}$ & $0.996^{b}$ \\
\hline Total disease course (years) & $\begin{array}{l}6.44 \pm \\
5.85\end{array}$ & $\begin{array}{l}6.87 \pm \\
4.81\end{array}$ & $\begin{array}{l}5.57 \pm \\
4.74\end{array}$ & $\begin{array}{l}6.42 \pm \\
4.96\end{array}$ & $\begin{array}{l}6.22 \pm \\
4.93\end{array}$ & $\begin{array}{l}7.60 \pm \\
4.14\end{array}$ & $\begin{array}{l}7.30 \pm \\
5.98\end{array}$ & $\begin{array}{l}5.87 \pm \\
4.63\end{array}$ & $\begin{array}{l}7.19 \pm \\
4.96\end{array}$ & $\begin{array}{l}6.66 \pm \\
4.98\end{array}$ & $\begin{array}{l}1.121^{\mathrm{a}} \\
1.300^{\mathrm{b}}\end{array}$ & $\begin{array}{l}0.350^{\mathrm{a}} \\
0.274^{\mathrm{b}}\end{array}$ \\
\hline MADRS & - & - & - & - & $\begin{array}{l}26.54 \pm \\
6.72\end{array}$ & $\begin{array}{l}23.00 \pm \\
10.70\end{array}$ & $\begin{array}{l}32.48 \pm \\
9.31\end{array}$ & $\begin{array}{l}31.11 \pm \\
6.17\end{array}$ & $\begin{array}{l}25.74 \pm \\
11.79\end{array}$ & - & - & - \\
\hline YMRS & $\begin{array}{l}15.75 \pm \\
8.78\end{array}$ & $\begin{array}{l}29.39 \pm \\
10.00\end{array}$ & $\begin{array}{l}31.45 \pm \\
12.29\end{array}$ & $\begin{array}{l}28.57 \pm \\
12.00\end{array}$ & $\begin{array}{l}21.60 \pm \\
7.62\end{array}$ & - & - & - & - & - & - & - \\
\hline \multicolumn{13}{|l|}{ Thyroid profiles } \\
\hline $\mathrm{TSH}(\mathrm{mU} / \mathrm{L})$ & $\begin{array}{l}2.37 \pm \\
1.14\end{array}$ & $\begin{array}{l}2.38 \pm \\
1.69\end{array}$ & $\begin{array}{l}2.21 \pm \\
1.43\end{array}$ & $\begin{array}{l}2.31 \pm \\
1.51\end{array}$ & $\begin{array}{l}2.11 \pm \\
1.07\end{array}$ & $\begin{array}{l}2.30 \pm \\
1.41\end{array}$ & $\begin{array}{l}2.60 \pm \\
1.87\end{array}$ & $\begin{array}{l}1.73 \pm \\
0.72\end{array}$ & $\begin{array}{l}2.30 \pm \\
1.51\end{array}$ & $\begin{array}{l}2.29 \pm \\
1.47\end{array}$ & $\begin{array}{l}1.013^{\mathrm{a}} \\
0.200^{\mathrm{b}}\end{array}$ & $\begin{array}{l}0.417^{\mathrm{a}} \\
0.819^{\mathrm{b}}\end{array}$ \\
\hline TТ3 (nmol/L) & $\begin{array}{l}1.41 \pm \\
0.40\end{array}$ & $\begin{array}{l}1.62 \pm \\
0.56\end{array}$ & $\begin{array}{l}2.18 \pm \\
2.74\end{array}$ & $\begin{array}{l}1.86 \pm \\
1.92\end{array}$ & $\begin{array}{l}1.53 \pm \\
0.37\end{array}$ & $\begin{array}{l}1.55 \pm \\
0.40\end{array}$ & $\begin{array}{l}1.39 \pm \\
0.47\end{array}$ & $\begin{array}{l}1.59 \pm \\
0.31\end{array}$ & $\begin{array}{l}1.50 \pm \\
0.40\end{array}$ & $\begin{array}{l}1.66 \pm \\
1.32\end{array}$ & $\begin{array}{l}2.043^{\mathrm{a}} \\
2.514^{\mathrm{b}}\end{array}$ & $\begin{array}{l}0.060^{\mathrm{a}} \\
0.083^{\mathrm{b}}\end{array}$ \\
\hline FT3 (pmol/L) & $\begin{array}{l}4.51 \pm \\
1.20\end{array}$ & $\begin{array}{l}9.67 \pm \\
18.25\end{array}$ & $\begin{array}{l}7.12 \pm \\
12.51\end{array}$ & $\begin{array}{l}8.10 \pm \\
15.05\end{array}$ & $\begin{array}{l}4.69 \pm \\
1.12\end{array}$ & $\begin{array}{l}4.32 \pm \\
1.13\end{array}$ & $\begin{array}{l}4.00 \pm \\
1.34\end{array}$ & $\begin{array}{l}4.62 \pm \\
1.05\end{array}$ & $\begin{array}{l}4.26 \pm \\
1.20\end{array}$ & $\begin{array}{l}6.03 \pm \\
10.23\end{array}$ & $\begin{array}{l}2.139^{a} \\
4.804^{b}\end{array}$ & $\begin{array}{l}0.049^{\mathrm{a}} \\
0.009^{\mathrm{b}}\end{array}$ \\
\hline$\pi 4(\mathrm{nmol} / \mathrm{L})$ & $\begin{array}{l}64.83 \pm \\
37.16\end{array}$ & $\begin{array}{l}69.27 \pm \\
53.03\end{array}$ & $\begin{array}{l}69.07 \pm \\
41.25\end{array}$ & $\begin{array}{l}68.84 \pm \\
46.50\end{array}$ & $\begin{array}{l}79.17 \pm \\
34.25\end{array}$ & $\begin{array}{l}76.82 \pm \\
29.27\end{array}$ & $\begin{array}{l}66.27 \pm \\
34.08\end{array}$ & $\begin{array}{l}78.97 \pm \\
37.06\end{array}$ & $\begin{array}{l}73.66 \pm \\
32.59\end{array}$ & $\begin{array}{l}71.88 \pm \\
39.45\end{array}$ & $\begin{array}{l}0.719^{\mathrm{a}} \\
0.965^{\mathrm{b}}\end{array}$ & $\begin{array}{l}0.635^{\mathrm{a}} \\
0.382^{\mathrm{b}}\end{array}$ \\
\hline FT4 (pmol/L) & $\begin{array}{l}13.34 \pm \\
5.97\end{array}$ & $\begin{array}{l}12.92 \pm \\
6.73\end{array}$ & $\begin{array}{l}13.64 \pm \\
6.32\end{array}$ & $\begin{array}{l}13.28 \pm \\
6.45\end{array}$ & $\begin{array}{l}14.07 \pm \\
6.29\end{array}$ & $\begin{array}{l}14.98 \pm \\
10.27\end{array}$ & $\begin{array}{l}11.69 \pm \\
6.35\end{array}$ & $\begin{array}{l}14.19 \pm \\
3.55\end{array}$ & $\begin{array}{l}13.73 \pm \\
8.27\end{array}$ & $\begin{array}{l}13.60 \pm \\
7.23\end{array}$ & $\begin{array}{l}0.998^{\mathrm{a}} \\
0.195^{\mathrm{b}}\end{array}$ & $\begin{array}{l}0.427^{\mathrm{a}} \\
0.823^{\mathrm{b}}\end{array}$ \\
\hline
\end{tabular}

n, number, \% percentage, SD standard deviation, MADRS Montgomery Depression Scale, YMRS Young mania Rating Scale, TSH thyroid-stimulating hormone, $\Pi 33$ total triiodothyronine, FT3 free triiodothyronine, $T 44$ total thyroxine, FT4 free thyroxine. ${ }^{a}$, comparison on 7 different diagnostic subgroups; ${ }^{b},{ }^{2}$ comparison on 3 different diagnostic subgroups combined 
Table 2 The incidences of abnormal hormone secretion among different diagnostic subgroups ( $\mathrm{n}, \%$ )

\begin{tabular}{|c|c|c|c|c|c|c|c|c|c|c|c|c|}
\hline & \multicolumn{4}{|c|}{ The bipolar manic group(BD-M) } & \multirow{2}{*}{$\begin{array}{l}\text { The } \\
\text { mixed } \\
\text { group } \\
\text { (BD-MIX) }\end{array}$} & \multicolumn{4}{|c|}{ The bipolar depressive group(BD-D) } & \multirow[t]{2}{*}{ total } & \multirow[t]{2}{*}{$x^{2}$} & \multirow[t]{2}{*}{ p } \\
\hline & BD-M I & BD-M II & BD-M III & total & & BD-D I & BD-D II & BD-D III & total & & & \\
\hline Number & 16 & 60 & 60 & 136 & 27 & 62 & 43 & 23 & 128 & 291 & - & - \\
\hline ITHS & $0(0.00)$ & $12(20.00)$ & $6(10.00)$ & $28(20.59)$ & $2(7.41)$ & $1(1.61)$ & $1(2.33)$ & $0(0.00)$ & $2(1.56)$ & $32(11.00)$ & $\begin{array}{l}\text { Fisher }=17.595^{\mathrm{a}} \\
28.469^{\mathrm{b}}\end{array}$ & $\begin{array}{l}0.002^{\mathrm{a}} \\
0.000^{\mathrm{b}}\end{array}$ \\
\hline DTHS & $9(56.25)$ & $30(50.00)$ & $28(46.67)$ & $67(49.26)$ & $12(44.44)$ & $31(50.00)$ & $26(60.47)$ & $7(30.43)$ & $57(43.75)$ & $64(21.99)$ & $\begin{array}{l}6.171^{\mathrm{a}} \\
0.656^{\mathrm{b}}\end{array}$ & $\begin{array}{l}0.409^{a} \\
0.718^{b}\end{array}$ \\
\hline Total & $9(56.25)$ & $42(70.00)$ & $34(56.67)$ & $95(69.85)$ & $14(51.85)$ & $32(51.61)$ & $27(62.80)$ & $7(30.43)$ & $59(45.31)$ & $96(32.99)$ & $\begin{array}{l}12.822^{\mathrm{a}} \\
15.676^{\mathrm{b}}\end{array}$ & $\begin{array}{l}0.045^{a} \\
0.000^{b}\end{array}$ \\
\hline
\end{tabular}

$n$ number; \% percentage, ITHS increased thyroid hormone secretion, DTHS decreased thyroid hormone secretion. ${ }^{\text {, }}$, comparison on 7 different diagnostic subgroups; ${ }^{\text {b }}$, comparison on 3 different diagnostic subgroups combined

\section{Correlative analysis of hormones secretion and symptoms in BD-M, BD-MIX, and BD-D groups}

For BD-M patients, pearson's correlation analysis showed that FT3 was positively correlated with the YMRS total score $(r=0.182, p=0.045)$. But, a correlation coefficient of $0<|\mathrm{r}| \leq 0.2$ is interpreted as almost no correlation. This indicates that the severity of clinical symptoms in BD-M patients is not highly correlated with FT3 levels. For BD-MIX patients, there was no significant correlation found between FT3 levels and the YMRS total score $(r=-0.110, p=0.696)$. And there was no relationship was found between FT3 levels and the MADRS total score $(r=-1.58, p=0.120)$ in the BD-D patients.

\section{Discussion}

The present study finds that, compared with BD-D patients, BD-M patients have higher serum FT3 levels, higher rate of thyroid hormone increased secretion and higher rate of total abnormality thyroid hormone secretion. These findings indicate that thyroid axis dysfunction is more severe in patients with a manic episode than patients with a depressive episode. Differences in age and sex cannot explain this result, as there is no statistically significant difference in age and sex between the $\mathrm{BD}-\mathrm{M}$ group and the $\mathrm{BD}-\mathrm{D}$ group. And, this result is not consistent with that obtained by $\mathrm{Li} \mathrm{C}$ et al., which found no significant differences in thyroid profiles in $\mathrm{BD}$ patients with different mood episodes [18]. In addition, the correlation analysis did not find a strong correlation between the severity of clinical symptoms and thyroid hormone levels in patients with $\mathrm{BD}$ across different mood states. Previous research has shown that thyroid hormones have a major effect on behavior and even can modulate the phenotypic expression of affective disorders. For example, hyperthyroidism or thyrotoxicosis has been shown to be related to forms of anxiety or mood lability, such as mania $[19,20]$. It follows from this, thyroid hormone levels may cause mood changes in BD patients. However, because this study was a cross-sectional study, a causal relationship between changes in thyroid hormone levels and mood swing in patients with BD cannot be demonstrated. Therefore, further prospective studies are needed to verify this hypothesis.

At present, drug therapy is the main treatment for BD. Most psychotropic drugs have thyroid side effects, wherein lithium salt is most well-known. Lithium inhibits the release of thyroid hormones and increases TRH-stimulated TSH, leading to goiter, clinical and subclinical hypothyroidism, but rarely to hyperthyroidism [21-23]. In this study, thyroid function of drug-naïve $\mathrm{BD}-\mathrm{M}$ patients is active. This indicates that the inhibition of thyroid function by lithium salt may be part of the reason why lithium salt can control acute manic episodes. Atypical antipsychotic drugs can, according to their dopamine antagonism profile, moderately interfere with TSH response to TRH without provoking major disturbances to thyroid function [12]. A recent population-based naturalistic study indicated that, lower serum FT4 levels were associated with the use of antipsychotics $(p=0.001)$, particularly quetiapine $(p=0.003)$ and olanzapine $(p=0.018)$, while there were no associations with serum TSH levels [24]. Reductions in TT4 and FT4 are the most common change in thyroid hormones with antidepressant treatment $[25,26]$. Besides, compared with the use of antipsychotics alone, using antipsychotics in combination with other psychotropic drugs, especially with antidepressants, was associated with lower FT4 level $(p<0.001,24]$. Therefore, the side effects of psychotropic drugs may be beneficial for BD$\mathrm{M}$ patients, but not for BD-D patients. In addition, in this study, $43.75 \%$ of untreated patients with bipolar depression had decreased thyroid hormone secretion. It is necessary to avoid the use of drugs that inhibit thyroid function, which may aggravate depression symptoms and reduce the effect of antidepressant treatment, in patients with bipolar depression [17]. It has been reported that, in rapid-cycling bipolar disorder and refractory bipolar disorder, adjunctive thyroid hormones can be effective [27-30]. Although findings from studies of the 
efficacy of thyroid augmentation have not been uniformly positive [31], in general, these strategies remain alternatives for treatment-resistant non-bipolar and bipolar depressions [32, 33]. In clinical practice, therefore, it is necessary to take into account the differences in thyroid hormone levels in patients with BD across different emotional states in choosing drug.

To our knowledge, this is the first study to independently compare thyroid hormone levels in different diagnostic subgroups of patients with drug-naive BD. One major advantage of the present study compared to previous studies was that all subjects were drug-naïve, thus avoiding the impact of drugs on thyroid function.

The current study has serval limitations. First, hormonal variables were evaluated at a single time point. Because TSH, T3, FT3, T4, and FT4 tests can vary significantly between day and night, the acquisition of hormone levels at multiple time points is an ideal choice to establish the reliability of hormone levels. Besides, we did not check thyroid auto antibodies, and could not rule out underlying thyroid disease. Second, compared with the BD-M and BD-D groups, people in the BDMIX group were too few, which may cause errors, so that cautions should be remained about the result that there was no significant difference in thyroid function between BD-M group and BD-D group and BD-MIX group. And, it have been found long that thyroid axis dysfunction is more common in bipolar mixed than in bipolar manic patients [34]. Finally, this study is a crosssectional study and cannot prove whether mood fluctuations in bipolar disorder are related to changes in thyroid function. Further prospective research is required.

\section{Conclusion}

These findings indicate that thyroid functions were significantly different between depressive and manic episodes in BD patients. In clinical practice, it is necessary to take into account the differences in thyroid hormone levels in patients with BD across different emotional states in choosing drug.

\section{Abbreviations}

BD: Bipolar disorder; ICD 10: International Classification of Diseases diagnostic Criteria, Edition 10 who; MADRS: Montgomery Depression Scale; YMRS: Young Mania Rating Scale; TRH: Thyrotropin-releasing hormone; TSH: Thyroid-stimulating hormone; FT3: Free triiodothyronine; TT3: Total triiodothyronine; FT4: Free thyroxine; TT4: Total thyroxine

\section{Acknowledgements}

None.

\section{Authors' contributions}

All authors made substantial contributions to the conception and design of this study. SNZ performed the data collection, the data analyses and wrote the manuscript; XZ, YLZ, HX, YWL and YXC helped with the data collection and the manuscript preparation. BZ and XLS contributed to the conception of the study and provided professional comments on the content. The author(s) read and approved the final manuscript.

\section{Funding}

This study was supported by West China Psychiatric Association, China. Grant ID: WCPASX-2016. The funders had no role in study design, data collection and analysis, decision to publish, or preparation of the manuscript.

Availability of data and materials

The datasets used and/or analysed during the current study are available from the corresponding author on reasonable request.

\section{Declarations}

Ethics approval and consent to participate

The study was approved by the China Ethics Committee of Registering Clinical Trials. The code of ethics review is CHIECRCT-80187. This study completed the clinical trial registration: Chinese Clinical Trials Registry,

ChiCTR1800019064, registered 24 October 2018, http://www.chictr.org.cn. All patients signed informed consent before the experiment. We guarantee that all data that identifies patients is anonymous. This includes, but is not limited to, the patient's name, address, place of work, date of birth, phone number, email address, medical record and patient ID, account number, license number, IP address, and complete or comparable photo or video.

\section{Consent for publication}

Not applicable.

\section{Competing interests}

The authors have declared that no competing interests exist. The authors report no conflicts with any product mentioned or concept discussed in this article.

\section{Author details}

${ }^{1}$ Mental Health Center, West China Hospital, Sichuan University, Chengdu, Sichuan, China. ${ }^{2}$ Sichuan Provincial Center for Mental Health, Sichuan Academy of Medical Sciences \& Sichuan Provincial People's Hospital, Chengdu, Sichuan, China.

Received: 4 January 2021 Accepted: 8 October 2021

Published online: 21 October 2021

\section{References}

1. Vieta E, Berk M, Schulze TG, Carvalho AF, Suppes T, Calabrese JR, et al. Bipolar disorders. Nat Rev Dis Primers. 2018;4:18008.

2. Merikangas KR, Jin R, He JP, Kessler RC, Lee S, Sampson NA, et al. Prevalence and correlates of bipolar Spectrum disorder in the world mental health survey initiative. Arch Gen Psychiatry. 2011;68(3):241-51.

3. Vojta C, Kinosian B, Glick H, Altshuler L, Bauer MS. Self-reported quality of life across mood states in bipolar disorder. Compr Psychiatry. 2001;42(3): $190-5$.

4. McIntyre RS, Calabrese JR. Bipolar depression: the clinical characteristics and unmet needs of a complex disorder. Curr Med Res Opin. 2019;35(11):1993-2005.

5. Simon GE, Ludman EJ, Unutzer J, Operskalski BH, Bauer MS. Severity of mood symptoms and work productivity in people treated for bipolar disorder. Bipolar Disord. 2008;10(6):718-25.

6. Cloutier M, Greene M, Guerin A, Touya M, Wu E. The economic burden of bipolar I disorder in the United States in 2015. J Affect Disord. 2018;226:45-51.

7. Martinez-Aran A, Vieta E, Torrent C, Sanchez-Moreno J, Goikolea JM, Salamero $\mathrm{M}$, et al. Functional outcome in bipolar disorder: the role of clinical and cognitive factors. Bipolar Disord. 2007;9(1-2):103-13.

8. Grande I, Goikolea JM, de Dios C, González-Pinto A, Montes JM, Saiz-Ruiz J, et al. Occupational disability in bipolar disorder: analysis of predictors of being on severe disablement benefit (PREBIS study data). Acta Psychiatr Scand. 2013;127(5):403-11.

9. Alonso J, Petukhova M, Vilagut G, Chatterji S, Heeringa S, Ustun TB, et al. Days out of role due to common physical and mental conditions: results from the WHO world mental health surveys. Mol Psychiatry. 2011;16(12): 1234-46.

10. Dome P, Rihmer Z, Gonda X. Suicide risk in bipolar disorder: a brief review. Medicina. 2019;55(8):403.

11. McKnight RF, Adida M, Budge K, Stockton S, Goodwin GM, Geddes JR. Lithium toxicity profile: a systematic review and meta-analysis. Lancet. 2012; 379(9817):721-8. 
12. Bou Khalil R, Richa S. Thyroid adverse effects of psychotropic drugs: a review. Clin Neuropharmacol. 2011;34(6):248-55.

13. Chakrabarti S. Thyroid functions and bipolar affective disorder. J Thyroid Res. 2011:2011:306367.

14. Szuba MP, Amsterdam JD, Fernando AT 3rd, Gary KA, Whybrow PC, Winokur A. Rapid antidepressant response after nocturnal TRH administration in patients with bipolar type I and bipolar type II major depression. J Clin Psychopharmacol. 2005;25(4):325-30.

15. Bottlender R, Rudolf D, Strauss A, Möller HJ. Are low basal serum levels of the thyroid stimulating hormone (b-TSH) a risk factor for switches into states of expansive syndromes known in Germany as "maniform syndromes" in bipolar I depression? Pharmacopsychiatry. 2000;33(2):75-7.

16. Larsen JK, Faber J, Christensen EM, Bendsen BB, Solstad K, Gjerris A, et al. Relationship between mood and TSH response to TRH stimulation in bipolar affective disorder. Psychoneuroendocrinology. 2004;29(7):917-24.

17. Cole DP, Thase ME, Mallinger AG, Soares JC, Luther JF, Kupfer DJ, et al. Slower treatment response in bipolar depression predicted by lower pretreatment thyroid function. Am J Psychiatry. 2002;159(1):116-21.

18. Li C, Lai J, Huang T, Han Y, Du Y, Xu Y, et al. Thyroid functions in patients with bipolar disorder and the impact of quetiapine monotherapy: a retrospective, naturalistic study. Neuropsychiatr Dis Treat. 2019;15:2285-90.

19. Bunevicius R, Velickiene D, Prange AJ Jr. Mood and anxiety disorders in women with treated hyperthyroidism and ophthalmopathy caused by Graves' disease. Gen Hosp Psychiatry. 2005;27(2):133-9.

20. Bunevicius R, Prange AJ Jr. Thyroid disease and mental disorders: cause and effect or only comorbidity? Curr Opin Psychiatry. 2010;23(4):363-8.

21. Kuman Tunçel Ö, Akdeniz F, Özbek SS, Kavukçu G, Ünal Kocabaş G. Thyroid function and ultrasonography abnormalities in Lithium-treated bipolar patients: a cross-sectional study with healthy controls. Noro Psikiyatr Ars. 2017;54(2):108-15.

22. Bocchetta A, Cocco F, Velluzzi F, Del Zompo M, Mariotti S, Loviselli A. Fifteen-year follow-up of thyroid function in lithium patients. J Endocrinol Investig. 2007;30(5):363-6.

23. Fagiolini A, Kupfer DJ, Scott J, Swartz HA, Cook D, Novick DM, et al. Hypothyroidism in patients with bipolar I disorder treated primarily with lithium. Epidemiologia e Psichiatria Sociale. 2006;15(2):123-7.

24. Vedal TSJ, Steen NE, Birkeland KI, Dieset I, Reponen El, Laskemoen JF, et al. Free thyroxine and thyroid-stimulating hormone in severe mental disorders: a naturalistic study with focus on antipsychotic medication. J Psychiatr Res. 2018;106:74-81.

25. Fatimi J, Lagorce JF, Chabernaud ML, Comby F, Buxeraud J, Raby C. Synthesis and antithyroid activity of 1,4,5-trialkyl 2-thioimidazole derivatives. Farmaco. 1994;49(4):253-7.

26. Joffe RT, Sokolov ST. Thyroid hormones, the brain, and affective disorders. Crit Rev Neurobiol. 1994;8(1-2):45-63.

27. Bauer M, Priebe S, Kürten I, Gräf KJ, Baumgartner A. Psychological and endocrine abnormalities in refugees from East Germany: part I. prolonged stress, psychopathology, and hypothalamic-pituitary-thyroid axis activity. Psychiatry Res. 1994;51(1):61-73.

28. Bauer M, Hellweg R, Gräf KJ, Baumgartner A. Treatment of refractory depression with high-dose thyroxine. Neuropsychopharmacology. 1998;18(6):444-55.

29. Stancer HC, Persad E. Treatment of intractable rapid-cycling manicdepressive disorder with levothyroxine. Clinical observations. Arch Gen Psychiatry. 1982;39(3):311-2.

30. Bauer MS, Whybrow PC, Winokur A. Rapid cycling bipolar affective disorder. I. Association with grade I hypothyroidism. Arch Gen Psychiatry. 1990;47(5):427-32.

31. Thase ME, Kupfer DJ, Jarrett DB. Treatment of imipramine-resistant recurrent depression: I. an open clinical trial of adjunctive L-triiodothyronine. J Clin Psychiatry. 1989:50(10):385-8.

32. Nierenberg AA, White K. What next? A review of pharmacologic strategies for treatment resistant depression. Psychopharmacol Bull. 1990;26(4):429-60.

33. Sachs GS. Treatment-resistant bipolar depression. Psychiatr Clin North Am. 1996:19(2):215-36.

34. Chang KD, Keck PE Jr, Stanton SP, McElroy SL, Strakowski SM, Geracioti TD Jr. Differences in thyroid function between bipolar manic and mixed states. Biol Psychiatry. 1998;43(10):730-3.

\section{Publisher's Note}

Springer Nature remains neutral with regard to jurisdictional claims in published maps and institutional affiliations.

\section{Ready to submit your research? Choose BMC and benefit from:}

- fast, convenient online submission

- thorough peer review by experienced researchers in your field

- rapid publication on acceptance

- support for research data, including large and complex data types

- gold Open Access which fosters wider collaboration and increased citations

- maximum visibility for your research: over $100 \mathrm{M}$ website views per year

At $\mathrm{BMC}$, research is always in progress.

Learn more biomedcentral.com/submissions 